\title{
Analysis of User Responses to the Application of Web-Based Assessment on Character Assessment
}

\author{
Tanti $^{1^{*}}$, Darmaji ${ }^{2}$, Astalini ${ }^{3}$, Dwi Agus Kurniawan ${ }^{4}$, Muhammad Iqbal ${ }^{5}$ \\ 1,2,3,4,5 Prodi Pendidikan Fisika, Universitas Jambi, Jambi, Indonesia \\ e-mail:tanyatanti25@gmail.com
}

\section{A R T I C L E I N F O \\ Article history: \\ Received April 06, 2021 \\ Revised April 11, 2021 \\ Accepted June 03, 2021 \\ Available online August 25, 2021}

\section{Kata Kunci:}

Pengembangan, Online,

Pembelajaran, LMS

Keywords:

Development, Online, Learning,

LMS

DOI:

https://dx.doi.org/10.23887/jet.v5 i3.33590

\begin{abstract}
A $B S T R A K$
Saat ini terdapat beberapa kendala dalam penilaian menggunakan media konvensional, antara lain penggunaan kertas yang berlebihan yang menyebabkan kerusakan lingkungan dan juga membengkaknya biaya sekolah hanya untuk melakukan penilaian. Selain itu, kurang efektifnya penilaian karena membutuhkan waktu yang lama untuk menilai hasil jawaban siswa secara manual. Media konvensional memungkinkan terjadinya kecurangan dan mengakibatkan kurangnya kepercayaan terhadap hasil penilaian. Penelitian ini bertujuan untuk menganalisis respon pengguna dalam menggunakan web-based assessment sebagai media penilaian karakter. Populasi penelitian ini berjumlah sebanyak 91 siswa. Penelitian ini menggunakan metode mix methodexplanatory dengan metode analisis deskriptif dan menggunakan metode kualitatif. Hasil penelitian menunjukan bahwa dari respon pengguna didapatkan nilai rata-rata sebesar 3,52 yang termasuk kategori SB (sangat baik) karena penggunaan website dapat menghemat waktu, menampilkan data real time, dan sangat mudah digunakan di mana saja, Dengan respon yang baik dari pengguna, web-based assessment ini layak untuk digunakan dalam penilaian karakter siswa. Implikasi penelitian ini yaitu web-based assessment dapat digunakan oleh guru dalam melakukan penilaian.
\end{abstract}

\section{A B S T R A C T}

There are currently several obstacles in the assessment using conventional media, including excessive use of paper, which causes environmental damage, and increases in school fees to conduct an assessment. In addition, it is less effective in conducting assessments because it takes a long time to assess the results of student answers manually. . Conventional media allows fraud and results in a lack of confidence in the assessment results. This study aims to analyze user responses using web-based assessment as a character assessment medium. The population of this study amounted to 91 students. This study uses a mixed-method explanatory method with descriptive analysis and qualitative methods. The results of the study show that the user response obtained an average value of 3.52, which includes the SB category (excellent) because the use of the website can save time, display real-time data, and is very easy to use anywhere, so with a good response from users make this web-based assessment suitable for use in student character assessment. This research implies that teachers can use web-based assessment in conducting assessments.

This is an open access article under the CC BY-SA license.

Copyright (C) 2021 by Author. Published by Universitas Pendidikan Ganesha.

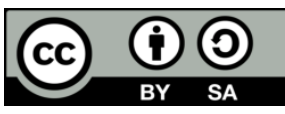

\section{INTRODUCTION}

Technology is a necessity for society in this 21 st century. In this century, technology that is developing very rapidly has an impact on the habits of people who experience dependence on technology (Almusawi et al., 2021; Chang et al., 2021; C.-H. Chen \& Tsai, 2021). The technology that is most often associated with society is a smartphone that has been used by many people because the portability and accessibility of smartphones allow users to access smartphones anywhere and for a long time (Cha \& Seo, 2018; Kim et al., 2012). The use of smartphones today can enter all spheres of life, one of which is the world of education, where learning can now use smartphones as a learning resource by utilizing content or information that can be channeled and searched for on smartphones (Kusuma et al., 2021; Mutambara \& Bayaga, 2021). By utilizing the capabilities of this smartphone, many application developers and web developers make innovations in the world of education which aim to facilitate all the needs of the world of education today. The things that underlie the use of learning using smartphones are the ease and flexibility it offers as well as minimizing the barriers inherent in traditional methods as is usually done in schools and to reduce the personal needs of students using smartphones during the learning process (Foen $\mathrm{Ng}$ et al., 2017;Synnott, 2018). With the flexibility of a smartphone it will make it easier 
for students to obtain information. Smartphones also function as interactive learning media in accordance with the needs of the times (C.-H. Chen \& Tsai, 2021; Sunismi, 2015).

The role of technology is very much needed in learning, especially in the field of assessment because the use of appropriate media will determine the success of the learning process and to create an interesting learning activity (McGarr \& Gallchóir, 2021; Zhang et al., 2021). Learning itself is very dependent on the results of the students to determine the success or failure of the learning carried out which we call assessment. In the 2013 curriculum, there are four aspects of assessment, namely 1) knowledge aspects, 2) skills aspects, 3) attitude aspects, and 4) behavioral aspects, which are aspects that must be assessed by the teacher so that potential apart from the cognitive domain can also be monitored and developed (Setiadi, 2016;Nugraha et al., 2017). All aspects of assessment are very important in learning in the 2013 curriculum because a student must not only be assessed based on his knowledge but must also be assessed from other aspects. The 2013 curriculum is a curriculum that emphasizes assessments that measure four things, namely: measuring the level of thinking of students from low to high, emphasizing questions that require deep thinking, measuring student work processes, and using portfolios (Maryani \& Martaningsih, 2017). The 2013 curriculum is referred to as character education, where the development of student character is as important as the development of student knowledge, besides that student attitudes are also a factor that must be developed and assessed as well (Tiara \& Sari, 2019).

Currently, many teachers have not been able to utilize technology optimally (Buchori et al., 2017; Rubini et al., 2018). In addition, there are still many teachers who have not been able to use technology to assess students. The need for electronic media, especially the web in the assessment, shows that currently there are several obstacles in assessing using conventional media, including excessive use of paper which causes environmental damage and also swelling school expenses just for conducting assessments; lack of effectiveness in conducting assessments because it takes a long time to assess the results of students' answers manually; and the inability of conventional media to demonstrate transparency in conducting assessments because timeconsuming assessments allow fraud and lead to a lack of trust in the results of the assessment (Danniels et al., 2020; Kaplan et al., 2021). Character education is an effort to help someone understand, pay attention to, and practice ethical values (Birhan et al., 2021; Singh, 2019; Yulianti et al., 2016).

Assessment which is an important factor in learning must be digitized to be able to develop methods that are accurate and bring very fast progress in assessment and learning and will save time than conventional methods (Alruwais et al., 2018;Afif, 2019). Online or internet-based assessments will be very effective in overcoming current constraints where distance learning is enforced, thus requiring teachers to conduct online assessments so as not to obstruct the assessment process, therefore digital assessment is very important (Ahmad, 2020; Hanifah Salsabila et al., 2020). From the existing obstacles, many are thinking about overcoming these obstacles with current technology. One of the technologies that can be utilized is the website. The web will be used as an assessment media that has the advantage of being able to provide feedback quickly. One of the instruments needed to assess students is an assessment instrument. Assessment instruments are intended to be used in practices that require adopting a competency perspective or alignment of assessment principles (Leutner et al., 2017). Currently the web is widely used as a container for data and information with unlimited pages and is used as an assessment media without being limited by space and time (Sari \& Setiawan, 2018). The creation of a web-based assessment as a supporting media in assessing student character is very helpful in overcoming obstacles in student character assessment such as overcoming paper wastage, streamlining time in assessment, overcoming large costs, and making students more focused in filling out characters assessment sheets.

Character education itself is emphasized on values that need to be understood, demonstrated and applied by students which include a sense of responsibility, honesty, care, and fairness (Muhtar \& Dallyono, 2020; Patterson \& A.Niesa, 2018). With good character education, it will be able to produce very intelligent students with the best character in accordance with the expectations of their social environment (Bates, 2019; Thoyyibah et al., 2019). Social observers show that the crisis in Indonesia comes from the failure of educational institutions to develop participant character behavior. In overcoming the moral crisis, the character building of students in educational institutions must be evaluated and must maximize the quality of learning in the classroom and the integration of intracurricular and extracurricular activities in schools (Juwantara, 2019; Sujatmiko et al., 2019). Delivering the right way will enable the realization of character, moral, social and physical habituation which will be instilled in the child to become a complete human being (Maryatun, 2016;Amran et al., 2020). Later, the implementation of these character values will be included in the lesson plan with the intention of achieving an ideal character and in accordance with the Minister of Education Regulation (Dalyono \& Lestariningsih, 2017). To see how student character education is required an assessment that is able to assess student character quickly and accurately which is called an assessment media.

The development of student character through character education is very mandatory to be applied in the world of education today because character is very important to build the Indonesian nation today. The character of students who are already very good and still need development, of course, needs to be measured by several indicators (Lian et al., 2020; Muhamad Nova, 2017). The quality of character education can at least be 
measured from several factors, including teachers, environment and so on, teachers play a very important role in shaping the character of students besides family because teachers can shape the character of students from examples of behavior they do in school (Suwartini, 2017 ;Yanto, 2020). The urgency of the current assessment is to use electronic-based assessment media, because currently with advanced technology it is hoped that it can increase the effectiveness and transparency in the assessment. Previously, research related to web-based assessment had been carried out by Wahyuningsih et al., (2016) who explained that web-based assessment could be used to assess the scientific attitude of students in schools.

In addition, web-based assessment will make it easier for teachers to make assessments. Although this research looks the same as previous research, by conducting research on assessing student character, of course the results of the research will be different because attitudes and characters are two different things that make this study different. In addition, the sample using this web-based assessment is different, so that new things will be obtained that are able to complement and support previous research. Based on the previous description, this study will examine how to analyze user responses to the use of web-based assessments on character assessments which will then be described. The purpose of this study is to see how the results of user responses to the application of web-based assessment as a media for character assessment. The results of this user response aim to see how well the web has been used by students so that from the student's response the researcher will develop a web-based assessment product so that it becomes better and more interesting.

\section{METHOD}

This study uses an explanatory design which is part of mixed methods research. Agustin (2019) explains that explanatory design is a research design that in the early stages uses quantitative methods and in the second stage uses qualitative methods. The data processing technique used is descriptive statistics in which Maswar (2017) explains that descriptive statistics are highly recommended to be used as a first step before doing other analysis on data, because it allows quickly to input and identify the data we input into a form. Data were collected through filling out a user response questionnaire which in this study were filled in by students who used the website. The user response questionnaire was adapted from research by Pratama \& Buditjahjanto (2016). Students will function in using the website as a media for character assessment and then students will fill out a user response questionnaire containing 30 statements whose grid can be seen in table 1 .

Table 1. User Response Questionnaire Grid

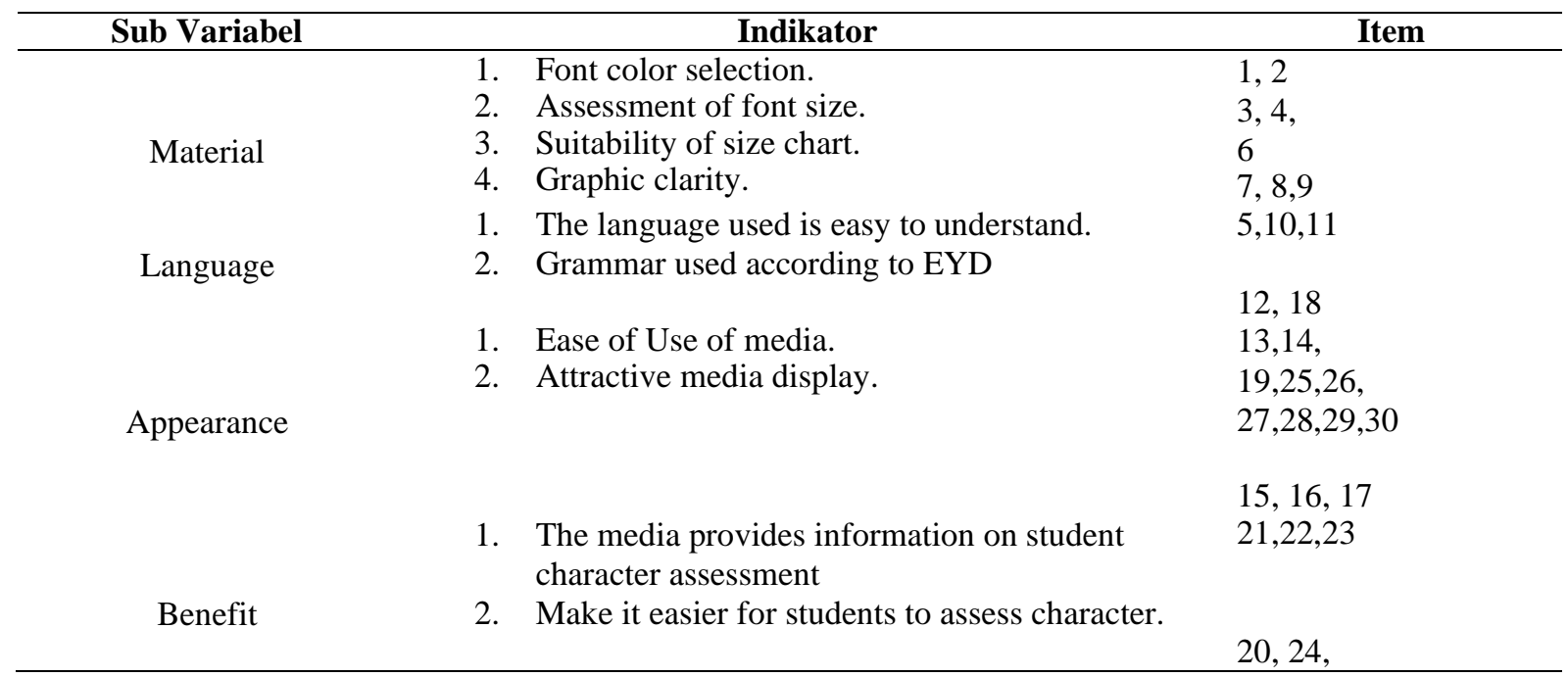

The assessment of the user response questionnaire in the form of a statement was changed to a Likert scale with 4 scales starting from, 1 for the STB category (very bad), 2 for the TB category (not good), 3 for category B (good), and a score of 4 for the SB category (very good). The population in this study were all students at SMPN 2 Batanghari where to take the sample the researcher used a purposive sampling technique. The sample selection using purposive sampling technique is a sampling technique through certain considerations and the sample is selected based on the researcher's judgment that the sample is the party who is able to provide quality information (Sugiyono, 2013). By using purposive sampling technique, the researcher will get a sample that is really in accordance with the research objective. The interviews were conducted with 90 respondents, namely students who used the web after the assessment was carried out with a web-based assessment. The interview used was a structured interview with open-ended questions. The researcher will ask several questions 
to see the respondent's response regarding the application of web-based assessment in student character assessment. The results of the interview are intended to strengthen the results of user responses collected through a questionnaire.

The results of the questionnaire will be analyzed using descriptive statistics. Descriptive statistics are statistics that study how to collect data and have a relationship about decomposing and providing information about data, which means that descriptive statistics function to explain the state of the data, descriptive statistics themselves consist of frequency, mean, median, mode, maximum and minimum values (Nasution, 2017). Frequency is a series of numerical data according to its quantity and quality which are arranged sequentially (Wahab et al., 2021). The mean is the average value of the data to see where the entire data is located, the median is the middle value of the data after being sorted and is also the average when viewed in terms of its position in the order of the data (Santi \& Eniyati, 2015). Mode is the value that occurs most often, the maximum value is the highest value of data and the minimum value is the lowest value of data (Kadir, 2015).

\section{RESULT AND DISCUSSION}

\section{Result}

The data were collected using 91 participants, consisting of 30 students of class VII, 30 students of class VIII, and 31 students of class IX. Data to the web-based student character assessment instrument shows that to get numbers from 91 respondents by producing valid data, the minimum value is 3.16 and the maximum value of user responses is 3.83 with a mean value of 3,52 , the median is 3.50 , and the mode is 3.50 . Based on the category, it was found that there were 88 respondents in the very good category and 3 respondents in the good category with the use of the student character assessment activity web. There are 4 indicators in the user response which consist of material review, language assessment, display assessment, and assessment of the benefits of the web. Based on data acquisition that has been analyzed, the percentage of each indicator is obtained in accordance with table 4.

Table 4. Results per user response assessment indicator

\begin{tabular}{lllllll}
\hline \multirow{2}{*}{ Indikator } & \multirow{2}{*}{ Rerata } & \multicolumn{4}{c|}{ Kategori } \\
\cline { 2 - 6 } & & STB (\%) & TB(\%) & B(\%) & \multicolumn{1}{c}{ SB(\%) } \\
\hline Materi & 3,59 & $0 \%$ & $0 \%$ & $4,4 \%$ & $95,6 \%$ \\
Bahasa & 3,44 & $0 \%$ & $0 \%$ & $30,7 \%$ & $69,3 \%$ \\
Tampilan & 3,49 & $0 \%$ & $0 \%$ & $12 \%$ & $88 \%$ \\
Manfaat & 3,52 & $0 \%$ & $0 \%$ & $17,5 \%$ & $82.5 \%$ \\
\hline
\end{tabular}

In the material indicator which contains an assessment of graphics, color selection, and letters, an average value of 3.59 is obtained with the very good category of $95.6 \%$ and the good category of $4.4 \%$ which means the value is in the range of 3.26 to 4.00. For language indicators that contain assessment of the form of words, EYD and language structure, the average value is 3.44 with the number of good categories as much as $30.7 \%$ and those in the very good category of $69.3 \%$. For display indicators that contain assessment of the interface from the web and the efficiency and ease of using the web, an average of 3.49 is obtained with a good category of $12 \%$ and a very good category of $88 \%$. For the indicators of benefits, which contain web usability assessments, an average of 3.52 was obtained with the good category of $17.5 \%$ and the very good category of $82.5 \%$. Based on the assessment of user responses as seen from the indicators, it can be concluded that in appearance, language, the benefits of usability, and from the color selection are very good so that the web used is very good for assessing student character.

The results of the analysis of the user response questionnaires that were filled in by students were supported by the results of interviews which showed that students as users expected the application of web-based assessments in the student character assessment process at SMPN 2 Batanghari, because the application of webbased assessments in character assessments made processing faster. and many other advantages. The online system assessment makes the assessment more efficient in terms of time, funding, and achievement of assessment goals (Sorensen, 2013; Wang et al., 2018). After filling in the user response questionnaire, interviews were conducted with students at SMPN 2 Batanghari related to the application of web-based assessment as a media for assessment. From the results of interviews with students at SMPN 2 that the use of web-based assessment as a media for assessing student character is very supported because it is very helpful in filling it very quickly and with more realtime and transparent results supported by its benefits in saving paper, another reason is that the use of the web -based assessment is very easy to access using either a smartphone or laptop by simply clicking on the desired answer, making students more thorough in filling it out. 
There are several more benefits in implementing web-based assessment, namely data analysis that can be carried out in a very fast time so that students can immediately see the character deficiencies. Traditional assessments that are usually carried out using gauze are usually less effective for assessing in real time so that digital assessment is needed to be able to make assessments more effective and real time (Alhefnawi, 2021; Ozan, 2019). Assessment using a web-based assessment has advantages in terms of cost, convenience, scoring, results, and reliability. To create a web, it requires an attractive appearance with features that can help users streamline the assessment process. The following is the appearance of the web as a media for assessing student character.

Respondents as assessors of user responses also really liked that this student character assessment activity did not need to download an application, but was only related to the internet as a media for connecting devices and web-based assessments. The use of web-based assessment instruments has several advantages, one of which is that users can access it anywhere as long as the user has an internet network (Ahmad, 2020; Sailer et al., 2021; Segers et al., 2018). minimize paper use and so that evaluation activities run efficiently and effectively, the solution is to use technology that can be used anywhere and anytime (C.-H. Chen \& Tsai, 2021; Darmaji et al., 2019; Kivunja, 2015). This is what makes students also support the application of web-based assessments as a mediua for character assessment because even though they are on the way students can still do character assessments.

With the effectiveness and connectivity of use, this is the advantage of the web as an assessment media that should begin to be implemented in schools in order to save costs. The reason for using web-based assessment as a media for character assessment is because currently with the advancement of technology, technology is increasingly needed in life (Bilik et al., 2020; Hamdunah et al., 2016; Mountaines et al., 2013). The use of technology as a means and media in activities at school is a demand from the increasingly advanced times (C.-H. Chen \& Tsai, 2021; Jang et al., 2021). By implementing a website which is the current technology as a media for character assessment, it is hoped that an assessment will be able to assess in real time and transparently without any cheating and as soon as possible the results can be analyzed by the teacher and then notified to students to improve or improve their character as soon as possible (Ediyanto, 2016). The results of the assessment using a web-based assessment make it possible not to make mistakes in the assessment because currently character is one of the important points in the development of education in Indonesia.

The creation of an increasingly advanced character assessment media means a good first step for schools in developing student character to be better in the hope that students are able to meet the current character competencies (Agnies zka Bates, 2019; Pane \& Rina Patriana, 2016). Apart from helping to accelerate improving and improving the character of students, the assessors using the web are also able to make schools a good example for students because they care about the future by conserving paper usage, which means that the school has instilled a caring character for the environment so that students can understand that by utilizing technology it can be make students become someone who cares about the environment. The character of caring for the environment is a manifestation of human attitudes towards the environment in the form of actions in everyday life which are efforts to prevent damage to the natural environment around them, as well as trying to repair all natural damage that has been occur (Nugroho et al., 2020; Purwanti, 2017; Suastra et al., 2017). The importance of implementing character assessment using a web-based assessment is that it is able to save expenses in the budget for student assessments who initially use paper that issued a large budget, so it can be minimized by using web-based assessment technology so that schools are able to keep up with the times and this is also one of the urgencies, of the importance of using web-based assessment as a media for assessing student character. In addition, the use of technology is also a form of application of character values that must be possessed by students with the enthusiasm of the teacher in learning it can certainly make teachers become role models and good examples for students to improve their character. The use of electronic media is an effective assessment to encourage students and teachers to access characters that are not accessible to traditional assessments (Irawan et al., 2012).

As well as the assessment using web-based assessments, this makes teacher assessments faster and also makes students get results as soon as possible so that teachers have time for further learning activities or assessments (Omofoye et al., 2021; Tsivitanidou \& Constantinos, 2016). In addition, the assessment using webbased assessment is able to make students think openly that the more we use technology (Chen \& Chen, 2019; Dahalan \& Hussain, 2010). For junior high school students, the faster the formation of good character will make these students more developed because from the start it has been shown that current technology is able to improve and enhance their character so that these students always use technology in the world of education, especially in character assessment. With character assessment using this web-based assessment students are also taught about how later character assessment using this web will be able to make it have a good character from the start beginning.

In this study, it has limitations, namely that only a small group test was carried out while for the large group it was not carried out where the population and sample of this study only came from SMP 2 Batanghari 
did not cover most of the junior high schools in Batanghari district. By using Web-based assessment, it is hoped that in the future teachers will be more accustomed to applying technology in all fields of education, both in learning and in assessment. By implementing this web-based assessment, it will enable teachers to make learning and assessment models that are more innovative and creative because of the availability of existing technology. By implementing this, in addition to advancing teachers, it also raises enthusiasm for teachers in improving student character.

\section{CONCLUSION}

Students as users have a positive response to the application of the web as a media for character assessment in schools. Through interviews, it was found that students were quite happy to use the web as a media of assessment because they could show the results directly so that they were able to reflect on themselves as soon as possible and also that students were not tired of filling out the questionnaire because they only needed to press a button. It can be seen that the use of web-based assessments should be applied in school assessments.

\section{REFERENCES}

Afif, N. (2019). Pengajaran dan Pembelajaran di Era Digital. IQ (Ilmu Al-Qur'an): Jurnal Pendidikan Islam, 2(01), 117-129. https://doi.org/10.37542/iq.v2i01.28.

Agnies zka Bates. (2019). Character Education and the Priority of Recognition. Cambrid Ge Journal of Educatio N, 49(6), 695-710. https://doi.org/10.1080/0305764X.2019.1590529.

Agustin, N. M. (2019). Kemampuan Penalaran Matematika Siswa melalui Model Pembelajaran Core and Pairs Check (CPC) pada Materi Statistika Siswa Kelas XI MA Ma'arif NU Jenggawah. JPM: Jurnal Pendidikan Matematika, 5(1), 47. https://doi.org/10.33474/jpm.v5i1.2629.

Ahmad, I. F. (2020). Alternative Assessment in Distance Learning in Emergencies Spread of Corona Virus Disease (Covid-19). Jurnal Pedagogik, 07(01), 210.

Alhefnawi, M. A. M. (2021). Assessing the Efficacy of Online Handouts and Active Lectures in Learning Outcomes at the Engineering Undergraduate Level. Ain Shams Engineering Journal, 40. https://doi.org/10.1016/j.asej.2021.02.012.

Almusawi, H. A., Durugbo, C. M., \& Bugawa, A. M. (2021). Innovation in Physical Education: Teachers' Perspectives on Readiness for Wearable Technology Integration. Computers \& Education, 167. https://doi.org/10.1016/j.compedu.2021.104185.

Alruwais, N., Wills, G., \& Wald, M. (2018). Advantages and Challenges of Using e-Assessment. International Journal of Information and Education Technology, 8(1), 34-37. https://doi.org/10.18178/ijiet.2018.8.1.1008.

Amran, A., Jasin, I., Perkasa, M., Satriawan, M., Irwansyah, M., \& Erwanto, D. (2020). Implementation of Education for Sustainable Development to Enhance Indonesian Golden Generation Character. Journal of Physics: Conference Series, 1521(4), 1-5. https://doi.org/10.1088/1742-6596/1521/4/042102.

Bates, A. (2019). Character Education and the 'Priority of Recognition'. Cambridge Journal of Education, 49(6), 695-710. https://doi.org/10.1080/0305764X.2019.1590529.

Bilik, Ö., Kankaya, E. A., \& Deveci, Z. (2020). Effects of Web-Based Concept Mapping Education on Students' Concept Mapping and Critical Thinking Skills: A Double Blind, Randomized, Controlled Study. Nurse Education Today, 86, 104312. https://doi.org/10.1016/j.nedt.2019.104312.

Birhan, W., Shiferaw, G., \& Tiruye, A. A. M. T. H. (2021). Exploring the Context of Teaching Character Education to Children in Preprimary and Primary Schools. Social Sciences \& Humanities Open, 4(1), 100171. https://doi.org/10.1016/j.ssaho.2021.100171.

Buchori, Rahmawati, S., \& Wardani, S. (2017). The Development of a Learning Media for Visualizing the Pancasila Values Based on Information and Communication Technology. Jurnal Cakrawala Pendidikan, 36(3), 502-521. https://doi.org/10.21831/cp.v36i3.12748.

Cha, S. S., \& Seo, B. K. (2018). Smartphone Use and Smartphone Addiction in Middle School Students in Korea: Prevalence, Social Networking Service, and Game Use. Health Psychology Open, 5(1), 1-15. https://doi.org/10.1177/2055102918755046.

Chang, H.-Y., Wu, H.-F., Chang, Y.-C., Tseng, Y.-S., \& Wang, Y.-C. (2021). The Effects of a Virtual Simulation-Based, Mobile Technology Application on Nursing Students' Learning Achievement and Cognitive Load: Randomized Controlled Trial. International Journal of Nursing Studies, 120. https://doi.org/10.1016/j.ijnurstu.2021.103948.

Chen, C.-H., \& Tsai, C.-C. (2021). In-Service Teachers' Conceptions of Mobile Technology-Integrated Instruction: Tendency towards Student-Centered Learning. Computers \& Education, 170(1). 
https://doi.org/10.1016/j.compedu.2021.104224.

Chen, C.-M., \& Chen, M.-C. (2019). Mobile Formative Assessment Tool Based on Data Mining Techniques for Supporting Web-Based Learning. Computers \& Education, 5(2). https://doi.org/10.1016/j.compedu.2008.08.005.

Dahalan, H. M., \& Hussain, R. M. R. (2010). Development of Web-Based Assessment in Teaching and Learning Management System (e-ATLMS). Procedia - Social and Behavioral Sciences, 9. https://doi.org/10.1016/j.sbspro.2010.12.144.

Dalyono, B., \& Lestariningsih, E. D. (2017). Implementasi Penguatan Pendidikan Karakter di Sekolah. Bangun Rekaprima, 03(2), 33-42.

Danniels, E., Pyle, A., \& DeLuca, C. (2020). The Role of Technology in Supporting Classroom Assessment in Play-Based Kindergarten. Teaching and Teacher Education, 88. https://doi.org/10.1016/j.tate.2019.102966.

Darmaji, Kurniawan, D. A., Astalini, Lumbantoruan, A., \& Samosir, S. C. (2019). Mobile Learning in Higher Education for the Industrial Revolution 4.0: Perception and Response of Physics Practicum. International Journal of Interactive Mobile Technologies (Vol. 13, Issue 9). https://doi.org/10.3991/ijim.v13i09.10948.

Ediyanto. (2016). Siklus Prapembelajaran Model Penilaian Formatif Web-Based pada Pembelajaran Fisika Materi Suhu dan Kalor untuk Siswa SMK Kelas X. Jurnal Pendidikan Fisika Indonesia, 12(2), 126136. https://doi.org/10.15294/jpfi.v12i2.5906.

Foen Ng, S., Syamimi Iliani Che Hassan, N., Hairunnisa Mohammad Nor, N., \& Ain Abdul Malek, N. (2017). The Relationship between Smartphone Use and Academic Performance: A Case of Students in a Malaysian Tertiary Institution. Malaysian Online Journal of Educational Technology, 5(4), 58-70.

Hamdunah, Yunita, A., Zulkardi, \& Muhafzan. (2016). Development a Constructivist Module and Web on Circle and Sphere Material with Wingeom Software. Journal on Mathematics Education, 7(2), 109116. https://doi.org/10.22342/jme.7.2.3536.109-116.

Hanifah Salsabila, U., Irna Sari, L., Haibati Lathif, K., Puji Lestari, A., \& Ayuning, A. (2020). Peran Teknologi dalam Pembelajaran di Masa Pandemi Covid-19. Al-Mutharahah: Jurnal Penelitian dan Kajian Sosial Keagamaan, 17(2), 188-198. https://doi.org/10.46781/al-mutharahah.v17i2.138.

Irawan, D., Astra, I. M., \& Bakri, F. (2012). Pengaruh Penerapan Penilaian Portofolio Online Web Based Learning terhadap Hasil Belajar Fisika Siswa Tingkat SMA. Influence of Implementation Online Portfolio Assessment of Web Based Learning Against the Students Learn Physics for High School Level. Jurnal Teknodik, 17(3), 299-316.

Jang, M., Aavakare, M., Nikou, S., \& Kim, S. (2021). The Impact of Literacy on Intention to Use Digital Technology for Learning: A Comparative Study of Korea and Finland. Telecommunications Policy, 45(7). https://doi.org/10.1016/j.telpol.2021.102154.

Juwantara, R. A. (2019). Efektivitas Ekstrakurikuler Pramuka dalam Menanamkan Karakter Jujur Disiplin dan Bertanggung Jawab pada Siswa Madrasah Ibtidaiyah. Premiere Educandum : Jurnal Pendidikan Dasar dan Pembelajaran, 9(2), 160-171. https://doi.org/10.25273/pe.v9i2.4994.

Kadir. (2015). Statistika Terapan: Contoh dan Analisis Data dengan Program SPSS/Lisrel dalam Penelitian (2nd ed.). Rajawali pers.

Kaplan, L. R., Farooque, M., Sarewitz, D., \& Tomblin, D. (2021). Designing Participatory Technology Assessments: A Reflexive Method for Advancing the Public Role in Science Policy Decision-Making. Technological Forecasting and Social Change, 171. https://doi.org/10.1016/j.techfore.2021.120974.

Kim, P., Buckner, E., Kim, H., \& Makany, T. (2012). A Comparative Analysis of a Game-Based Mobile Learning Model in Low-Socioeconomic Communities of India. International Journal of Educational Development, 3(2). https://doi.org/10.1016/j.ijedudev.2011.05.008.

Kivunja, C. (2015). Unpacking the Information, Media, and Technology Skills Domain of the New Learning Paradigm. International Journal of Higher Education, 4(1). https://doi.org/10.5430/ijhe.v4n1p166.

Kusuma, G. P., Suryapranata, L. K. P., \& Utomo, Y. (2021). Enhancing Historical Learning Using Role-Playing Game on Mobile Platform. Procedia Computer Science, 179. https://doi.org/10.1016/j.procs.2021.01.078.

Leutner, D., Fleischer, J., Grunkorn, J., \& Klieme, E. (2017). Competence Assessment in Education Research, Models and Instruments. Springer Nature. https://doi.org/10.1007/978-3-319-50030-0_16.

Lian, B., Kristiawan, M., Ammelia, D., Primasari, G., Anggung, M., \& Prasetyo, M. (2020). Teachers' Model in Building Students' Character. Journal of Critical Reviews, 7(14), 927-932. https://doi.org/10.31838/jcr.07.14.165.

Maryani, I., \& Martaningsih, S. T. (2017). Persepsi Guru Sekolah Dasar terhadap Sistem Penilaian pada Kurikulum 2013. Scholaria: Jurnal Pendidikan dan Kebudayaan, 7(2), $153-164$. https://doi.org/10.24246/j.scholaria.2017.v7.i2.p153-164. 
Maryatun, I. B. (2016). Peran Pendidik PAUD dalam Membangun Karakter Anak. Jurnal Pendidikan Anak, 5(1), 747-752. https://doi.org/10.21831/jpa.v5i1.12370.

Maswar, M. (2017). Analisis Statistik Deskriptif Nilai UAS Ekonomitrika Mahasiswa dengan Program SPSS 23 \& Eviews 8.1. Jurnal Pendidikan Islam Indonesia, 1(2), 273-292. https://doi.org/10.35316/jpii.v1i2.54.

McGarr, O., \& Gallchóir, C. Ó. (2021). Examining Supervising Field Instructors' Reporting and Assessment of Technology Use by Pre-Service Teachers on School Placement. Computers \& Education, 146. https://doi.org/10.1016/j.compedu.2019.103753.

Mountaines, Satoto, \& Kridalukmana. (2013). Pengembangan Aplikasi Berbasis Web untuk Menampilkan Absensi dan Nilai Akhir Peserta Didik (Studi Kasus di SMP Negeri 32 Semarang). Jurnal Teknologi Dan Sistem Komputer, 1(4). https://doi.org/10.14710/jtsiskom.1.4.2013.129-144.

Muhamad Nova. (2017). Character Education In Indonesia EFL Classroom Implementation and Obstacles. Jurnal Pendidikan Karakter, 7(2). https://doi.org/10.21831/jpk.v7i2.13650.

Muhtar, T., \& Dallyono, R. (2020). Character Education from the Perspectives of Elementary School Physical Education Teachers. Jurnal Cakrawala Pendidikan, 39(2), 395-408. https://doi.org/10.21831/cp.v39i2.30647.

Mutambara, D., \& Bayaga, A. (2021). Determinants of Mobile Learning Acceptance for STEM Education in Rural Areas. Computers \& Education, 160. https://doi.org/10.1016/j.compedu.2020.104010.

Nasution, L. M. (2017). Statistik Deskriptif. Jurnal Hikmah, 14(1), 49-55. https://doi.org/10.1021/ja01626a006.

Nugraha, R., Purnamasari, I., \& Baedowi, S. (2017). Evaluasi Penerapan Standar Penilaian Kurikulum 2013 pada Kelas 4 Sekolah Dasar di Kecamatan Jambu. Jurnal Sekolah, 2(1), 94. https://doi.org/10.24114/js.v2i1.9925.

Nugroho, A. A., Dwijayanti, I., \& Atmoko, P. Y. (2020). Pengaruh Model Pembelajaran Berbasis Penemuan dan Lingkungan terhadap Kemampuan Pemecahan Masalah Matematika melalui Meta Analisis. Aksioma, 9(1). https://doi.org/10.24127/ajpm.v9i1.2659.

Omofoye, T. S., Leong, L. C. H., Kalambo, M., Teo, S. Y., \& Lim, W. E. H. (2021). Responsive Web-based Breast Imaging Core Curriculum for International Radiology Residents with Self-Assessment: A Pilot Study. Academic Radiology, 11. https://doi.org/10.1016/j.acra.2021.07.004.

Ozan, C. (2019). The Effect of Authentic Assessment on Academic Achievement and Attitude towards Educational Measurement and Opinions of Prospective Teachers. International Journal of Evaluation and Research in Education, 8(2), 299-312. https://doi.org/10.11591/ijere.v8i2.18564.

Pane, M. M., \& Rina Patriana. (2016). The Significance of Environmental Contents in Character Education for Quality of Life. Procedia - Social and Behavioral Sciences, 222, 244-252. https://doi.org/10.1016/j.sbspro.2016.05.153.

Patterson, K., \& A.Niesa, S. M. (2018). Transforming Nursing Education in a 140-Character World: The Efficacy of Becoming Social. Journal of Professional Nursing, 34(1), 31-34. https://doi.org/10.1016/j.profnurs.2017.07.001.

Pratama, A. P., \& Buditjahjanto, I. G. P. A. (2016). Pengembangan Media Pembelajaran Berbasis Web (Web Based Learning) pada Mata Pelajaran Dasar Kompetensi Kejuruan pada Siswa Kelas XII Tei, di SMK Negeri 1 Sukorejo, Pasuruan. Jurnal Pendidikan Teknik Elektro, 5(2), 567-574. https://jurnalmahasiswa.unesa.ac.id/index.php/index/index.

Purwanti, D. (2017). Pendidikan Karakter Peduli Lingkungan dan Implementasinya. DWIJA CENDEKIA: Jurnal Riset Pedagogik, 1(2), 14-20. https://doi.org/10.20961/jdc.v1i2.17622.

Rubini, B., Permanasari, A., \& Yuningsih, W. (2018). Learning Multimedia Based on Science Literacy on the Lightning Theme. Jurnal Penelitian Dan Pembelajaran IPA, 4(2), 89-104. https://doi.org/10.30870/jppi.v4i2.3926.

Sailer, M., Stadler, M., Schultz-Pernice, F., Franke, U., \& Schöffmann, C. (2021). Technology-Related Teaching Skills and Attitudes: Validation of a Scenario-Based Self-Assessment Instrument for Teachers. Computers in Human Behavior, 115. https://doi.org/10.1016/j.chb.2020.106625.

Santi, R. C. N., \& Eniyati, S. (2015). Implementasi Statistik dengan Database Mysql. Jurnal Teknologi Informasi DINAMIK, 20(2), 132-139. https://doi.org/10.35315/dinamik.v20i2.4645.

Sari, P. A., \& Setiawan, A. (2018). The Development of Internet-Based Economic Learning Media using Moodle Approach. International Journal of Active Learning, 3(2), 100-109. https://journal.unnes.ac.id/nju/index.php/ijal/article/view/13449.

Segers, M., Martens, R., \& Bossche, P. Van den. (2018). Understanding How a Case-Based Assessment Instrument Influences Student Teachers' Learning Approaches. Teaching and Teacher Education, 24(7). https://doi.org/10.1016/j.tate.2008.02.022.

Setiadi, H. (2016). Pelaksanaan Penilaian pada Kurikulum 2013. Jurnal Penelitian Dan Evaluasi Pendidikan, 20(2), 166-178. https://doi.org/10.21831/pep.v20i2.7173.

Singh, B. (2019). Character Education in the 21'st Century. Journal of Social Studies (JSS), 15(1), 1-12. 
https://doi.org/10.21831/jss.v15i1.25226.

Sorensen, E. (2013). Implementation and Student Perceptions of E-Assessment in a Chemical Engineering Module. European Journal of Engineering Education, 38(2), 172-185. https://doi.org/10.1080/03043797.2012.760533.

Suastra, I. W., Jatmiko, B., Ristiati, N. P., \& Yasmini, L. P. B. (2017). Developing Characters Based on Local Wisdom of Bali in Teaching Physics in Senior High School. Jurnal Pendidikan IPA Indonesia, 6(2), 306-312. https://doi.org/10.15294/jpii.v6i2.10681.

Sugiyono. (2013). Metode Penelitian Pendidikan. Alfabeta.

Sujatmiko, I. N., Arifin, I., \& Sunandar, A. (2019). Penguatan Pendidikan Karakter di SD. Jurnal Pendidikan, 4(8), 200-215. https://doi.org/10.24090/jk.v5i2.2109.

Sunismi. (2015). Developing Guided Discovery Learning Materials Using Mathematics Mobile Learning Application as an Alternative Media for the Students Calculus II. Cakrawala Pendidikan, 34(5). https://doi.org/10.21831/cp.v3i3.7340.

Suwartini, S. (2017). Pendidikan Karakter dan Pembangunan Sumber Daya Manusia Keberlanjutan. Trihayu: Jurnal Pendidikan Ke-SD-an, 4(1), 220-234. https://doi.org/10.30738/trihayu.v4i1.2119.

Synnott, K. C. (2018). Smartphones in the Classroom: Students' Misperceptions. Journal of Higeher Education Management, 33(1), 119-135. https://doi.org/10.2139/ssrn.3038013.

Thoyyibah, N., Hartono, R., \& Bharati, D. A. L. (2019). The Implementation of Character Education in the English Teaching Learning Using 2013 Curriculum. English Education Journal, 9(2), 254-266. https://doi.org/10.15294/eej.v9i2.30058.

Tiara, S. K., \& Sari, E. Y. (2019). Analisis Teknik Penilaian Sikap Sosial Siswa dalam Penerapan Kurikulum 2013 di SDN 1 Watulimo. EduHumaniora | Jurnal Pendidikan Dasar Kampus Cibiru, 11(1), 21. https://doi.org/10.17509/eh.v11i1.11905.

Tsivitanidou, O. E., \& Constantinos. (2016). A Study of Students' Heuristics and Strategy Patterns in WebBased Reciprocal Peer Assessment for Science Learning. The Internet and Higher Education, 29. https://doi.org/10.1016/j.iheduc.2015.11.002.

Wahab, A., Syahid, A., \& Junaedi, J. (2021). Penyajian Data dalam Tabel Distribusi Frekuensi dan Aplikasinya pada Ilmu Pendidikan. Education and Learning Journal, 2(1), 40-48. https://doi.org/10.33096/eljour.v2i1.91.

Wahyuningsih, R., Wahyuni, S., \& Lesmono, A. D. (2016). Pengembangan Instrumen Self Assessment Berbasis Web untuk Menilai Sikap Ilmiah pada Pembelajaran Fisika di SMA. Jurnal Pembelajaran Fisika, 4(4), 338-343. https://jurnal.unej.ac.id/index.php/JPF/article/view/3087.

Wang, S., Jiao, H., Young, M. J., Brooks, T., \& Olson, J. (2018). Comparability of Computer-Based and Paperand-Pencil Testing in K-12 Reading Assessments: A Meta-Analysis of Testing Mode Effects. Educational and Psychological Measurement, 68(1). https://doi.org/10.1177/0013164407305592.

Yanto, M. (2020). Manajemen Kepala Madrasah Ibtidaiyah dalam Menumbuhkan Pendidikan Karakter Religius pada Era Digital. Jurnal Konseling dan Pendidikan, 8(3), 176-183. https://doi.org/10.29210/146300.

Yulianti, D., Khanafiyah, S., \& Sulistyorini, S. (2016). Inquiry-Based Science Comic Physics Series Integrated with Character Education. Jurnal Pendidikan IPA Indonesia, 5(1), 38-44. https://doi.org/10.15294/jpii.v5i1.5787.

Zhang, H., Daim, T., \& Zhang, Y. (Peggy). (2021). Integrating Patent Analysis into Technology Roadmapping: A Latent Dirichlet Allocation Based Technology Assessment and Roadmapping in the Field of Blockchain. Technological Forecasting and Social Change, 167. https://doi.org/10.1016/j.techfore.2021.120729. 